Article

\title{
Variation of Phytoestrogen Content and Major Agronomic Traits in Alfalfa (Medicago sativa L.) Populations
}

\author{
Marijana Tucak ${ }^{1, *}$, Tihomir Čupić ${ }^{1}$, Daniela Horvat ${ }^{1} \mathbb{D}$, Svetislav Popović $^{1}$, Goran Krizmanić $^{1}$ \\ and Marija Ravlić ${ }^{2}$ \\ 1 Agricultural Institute Osijek, Južno predgrađe 17, 31000 Osijek, Croatia; tihomir.cupic@poljinos.hr (T.Č.); \\ daniela.horvat@poljinos.hr (D.H.); svetislav.popovic@poljinos.hr (S.P.); goran.krizmanic@poljinos.hr (G.K.) \\ 2 Faculty of Agrobiotechnical Sciences Osijek, Josip Juraj Strossmayer University of Osijek, Vladimir Prelog 1, \\ 31000 Osijek, Croatia; mravlic@fazos.hr \\ * Correspondence: mtucak@poljinos.hr; Tel.: +385-31-515-540
}

Received: 13 December 2019; Accepted: 6 January 2020; Published: 8 January 2020

check for updates

\begin{abstract}
Alfalfa is the main perennial legume and a rich source of phytoestrogens. Variation of phytoestrogen content and agronomic traits was evaluated in twenty alfalfa populations over two consecutive years. The most dominant phytoestrogen in alfalfa populations was genistein, while slightly lower levels were found for kaempferol and coumestrol. Several populations (Af 1, 12, 18, 19,20 ) showed superior agronomic performance, especially high forage yield (up to $71.93 \mathrm{tha}^{-1}$ ). These populations were also characterized by a lower (Af 1, 12, 18, 20) or high (Af 1, 19) content of total and individual phytoestrogens, including Af 8 population with the highest total content (2637.10 $\mu \mathrm{g} \mathrm{g}^{-1}$ of DM) and content of most of the individual phytoestrogens and favorable agronomic properties. Ward hierarchical clustering method grouped the twenty evaluated populations into four distinct clusters. Identified materials provide a valuable source of germplasm for further breeding programs in order to develop new high-yielding cultivars with either low (for forage use) or high (for possible pharmaceuticals/nutraceuticals industries) phytoestrogen content.
\end{abstract}

Keywords: alfalfa; Medicago sativa L.; phytoestrogens; agronomic traits; variation; HPLC; cluster analysis

\section{Introduction}

Alfalfa is the main perennial legume in the most temperate regions, primarily used as animal feed and it is universally considered one of the highest-quality forages. It is a valuable crop because of numerous agronomic and environmental advantages in terms of preserving soil fertility and biodiversity, soil erosion protection, mitigation of climate change impacts, reduction of groundwater nitrate pollution, fossil fuel consumption, greenhouse gas emissions etc., [1-5]. Most of the research studies of alfalfa breeding programs worldwide focused on development of new cultivars with increased yield and forage quality, good persistence and tolerance to different biotic/abiotic stresses $[3,5]$.

Alfalfa, like other legumes, is a rich source of phytoestrogens. These are phenolic non-steroidal compounds with a similar steric structure as steroidal estrogens [6]. This similarity gives them the ability to bind to estrogen receptors and exert estrogenic and/or anti-estrogenic effects. The most common phytoestrogens are isoflavones, lignans, and coumestans.

Nowadays, phytoestrogens are very interesting biochemical molecules which possess a wide range of human health benefits such as prevention of menopausal symptoms, osteoporosis, breast and prostate cancers, and cardiovascular diseases as reported by numerous studies [6-13]. Gatouillat et al. [8] 
showed that flavonoids (medicarpin, millepurpan, tricin, and chrysoeriol) from alfalfa extract can induce cytotoxic effects on tumor cells, which indicates that they have potential in cancer chemoprevention and therapy. In the United States and EU markets numerous herbal supplements are available, and the tendency to use them is steadily increasing. According to World Health Organization (WHO), around $80 \%$ of the world population use herbal preparations in some form of primary health care [14].

Alfalfa has recently become interesting as a potential source of secondary metabolites. There are several key reasons for a considerable interest in alfalfa as well as in red clover as a valuable alternative source of phytoestrogens for many health-related applications (human food ingredient and supplements) such as widespread growth across different continents; high adaptability to a wide range of cultivation, different soil types, different $\mathrm{pH}$ values, and environmental conditions either as natural populations or selected crops; possibility of sustainable and environmentally friendly production; limited use of soybean, currently a major source of isoflavonoids in human nutrition, because of the allergenic reactions it can cause in some people; steadily increasing production area of genetically modified soybeans that is not approved by many people and scientists [15-17].

Phytoestrogen compounds are also of interest because of their both positive and negative effects on animal health. Feeding animals on forages with high isoflavone concentrations have desirable impact on quicker weight gain of lambs, as well as on cows' milk production $[18,19]$. A strong association between formononetin intake and equol concentration in plasma was demonstrated, so that cows' milk can be considered as a source of equol in human nutrition [20-25]. On the other hand, consumption of forages with high concentrations of formononetin and coumestrol has shown to cause temporary or permanent reproductive problems in some ruminants, mostly in sheep and cattle [26-30].

Considering the presented data, studies related to phytoestrogens represent important challenges for forage crops breeders whose activities/plant selection should be focused on the development of new cultivars combining good agronomic performances with a low or high phytoestrogens concentration for their application in livestock production or nutraceutical and pharmaceutical industry.

The objectives of this study are to: (1) Determine and quantify phytoestrogen content in alfalfa populations, (2) evaluate variation of phytoestrogen content and agronomic traits in alfalfa materials, (3) identify a most promising germplasm for further breeding programs aimed for development of high yielding cultivars with desirable content of phytoestrogens for medical purposes or forage.

\section{Materials and Methods}

\subsection{Plant Material and Experimental Design}

Twenty alfalfa populations (Af 1 to Af 20) were evaluated over two consecutive years (2014-2015) in a field trial established at the beginning of March 2014 on the Agricultural Institute Osijek in Croatia. Seeds of each population were directly planted by hand into plots consisting of six rows each with a length of $6 \mathrm{~m}$ spaced approximately $20 \mathrm{~cm}$ apart. The seeding rate was $15 \mathrm{~g}$ per plot (approximately $18 \mathrm{~kg} \mathrm{ha}^{-1}$ ). The size of each experimental plot was $8.4 \mathrm{~m}^{2}$. The experimental design was a randomized complete block with four repetitions consisting of a total of 80 plots. Herbicides and fertilizers were not applied in the trials.

\subsection{Agronomic Data Collection}

Plots were harvested for forage biomass determination every four weeks on the following dates: 20 June, 21 July, 26 August, and 30 September in 2014; and on 8 May, 8 June, 7 July, 12 August, 14 September, and 20 October in 2015. Whole plots were harvested and weighed with a sickle bar harvester equipped with an electronic weigh system (Hege Model 212, Wintersteiger AG, Waldenburg, Germany). The phenological stage of all cuttings was full bud to beginning of flowering. Total yearly green mass yields for each plot were determined by summing the biomass yield from each harvest during each year. Yields were expressed as the average annual yield in the investigated two-year experiments (GMY, $\mathrm{t} \mathrm{ha}^{-1}$ ). Plant height was measured directly before each cutting on all plots of each 
population on ten randomly selected plants (from the ground to the top of the inflorescence) from the middle row of the plot $(\mathrm{PH}, \mathrm{cm})$. In order to determine the dry matter content in green mass an average sample of approximately $500 \mathrm{~g}$ of green mass was collected from the middle of each plot of all populations in all cuts in both years of research, placed in a paper bag and immediately taken to the laboratory. The samples were dried at $105^{\circ} \mathrm{C}$ for $24 \mathrm{~h}$ to establish the dry matter content (DMC, \%).

\subsection{Weather Conditions at the Experimental Site}

The average monthly air temperatures during the alfalfa-growing season in both investigated years, except May 2014, were higher or the same compared to the long-term average. Accordingly, the average annual air temperature in the growing season was higher by $1.1^{\circ} \mathrm{C}$ in 2014 and by $1.5^{\circ} \mathrm{C}$ in 2015 compared to the long-term average (Table 1). A higher total amount of precipitation was recorded in both investigated years compared to the long-term average, especially in 2014 which had 30\% more precipitation compared to the long-term average. Longer drought periods were not recorded, except for slightly less precipitation in April, June, and July in the second investigated year. However, this did not significantly affect the growth and development of the established alfalfa which developed a deep and strong root system.

Table 1. Average air temperature $\left({ }^{\circ} \mathrm{C}\right)$ and monthly precipitation $(\mathrm{mm})$ in Osijek, Croatia from March to October and a long-term average (LTA).

\begin{tabular}{ccccccc}
\hline \multirow{2}{*}{ Month } & \multicolumn{3}{c}{ Temperature $\left({ }^{\circ} \mathbf{C}\right)$} & \multicolumn{3}{c}{ Precipitation (mm) } \\
\cline { 2 - 7 } & $\mathbf{2 0 1 4}$ & $\mathbf{2 0 1 5}$ & LTA & $\mathbf{2 0 1 4}$ & $\mathbf{2 0 1 5}$ & LTA \\
\hline March & 9.5 & 7.5 & 6.4 & 39.4 & 50.5 & 40.5 \\
April & 13.2 & 12.1 & 11.2 & 81.3 & 12.9 & 51.0 \\
May & 16.1 & 17.8 & 16.7 & 161.4 & 113.4 & 59.2 \\
June & 20.5 & 20.8 & 19.9 & 91.0 & 17.1 & 82.0 \\
July & 21.8 & 24.6 & 21.3 & 66.4 & 25.6 & 66.3 \\
August & 20.8 & 23.7 & 20.8 & 54.3 & 105.8 & 61.9 \\
September & 17.0 & 17.9 & 16.5 & 68.9 & 41.1 & 51.0 \\
October & 13.3 & 11.1 & 11.1 & 87.9 & 142.1 & 55.9 \\
Mean/Total & 16.5 & 16.9 & 15.4 & 650.6 & 508.5 & 467.8 \\
\hline
\end{tabular}

Source: Meteorological and Hydrological Service of the Republic of Croatia.

\subsection{Field Sampling and Sample Preparation for Biochemical Analysis}

In the second cut of alfalfa in an early flowering stage in both years of research (June 2014 and July 2015), the average leaf samples (i.e., the healthy, young, and fully developed ones) from four repetitions of all populations were randomly collected from ten plants in the middle of each plot. The collected leaf samples were stored in a refrigerator $\left(-80^{\circ} \mathrm{C}\right)$, lyophilized, and ground into a fine powder by an oscillating mill immediately before extraction.

\subsection{Extraction Procedure}

The extraction of phytoestrogens was performed according to the partially modified procedure of Ramos et al. [31], as follows: The homogenized alfalfa samples $(0.1 \mathrm{~g})$ were extracted with $4 \mathrm{~mL}$ of hydrochloric acid $(6 \mathrm{M} \mathrm{HCl})$ and incubated in a water bath for $15 \mathrm{~min}$ at $100{ }^{\circ} \mathrm{C}$, with occasional vortexing. After cooling, the extracts were filtered and the residue was washed with $5 \mathrm{~mL}$ of $\mathrm{MeOH}$. The purified samples were filtered to a volumetric flask up to $10 \mathrm{~mL}$ and diluted to volume with distilled water, being centrifuged thereafter for $10 \mathrm{~min}$ at $4000 \mathrm{rpm}$. The obtained extracts were kept at $-21{ }^{\circ} \mathrm{C}$ until a high-performance liquid chromatography (HPLC) analysis was performed. Each sample was extracted as duplicates. Before HPLC injections extracts were filtered through a $0.45 \mu \mathrm{m}$ membrane filter. 


\subsection{Chromatographic Identification and Quantification of Phytoestrogens}

Phytoestrogens separations were carried out on a Perkin Elmer LC 200 Chromatograph system equipped with Total-Chrom Software Package, diode array detector (DAD) and RP-C18 column (Nova-Pak, $4 \mu \mathrm{m}, 3.9 \times 150 \mathrm{~mm}$ ). Elution was performed using the mobile phase solvents water: $0.1 \%$ trifluoroacetic acid $(v / v)(\mathrm{A})$ and acetonitrile: $0.1 \%$ trifluoroacetic acid $(\mathrm{B})$. Phytoestrogens were separated by injection of $30 \mu \mathrm{L}$ of extract and using a linear gradient of B from 25 to $50 \%$ for 15 min, with a flow rate of $1 \mathrm{~mL} / \mathrm{min}$ and at a column temperature of $30^{\circ} \mathrm{C}$. The wavelength of detection was $260 \mathrm{~nm}$. Phytoestrogens were identified according to standards retention time and UV spectra while their quantification were carried out by the external standard calibration at six different concentrations ranging from 0.05 to $2 \mu \mathrm{g} \mathrm{mL}^{-1}$ for daidzein, formononetin, biochanin $\mathrm{A}$, and prunetin and from 1 to $20 \mu \mathrm{g} \mathrm{mL}^{-1}$ for glycitein, genistein, coumestrol, and kaempferol. The determination coefficients $\left(\mathrm{r}^{2}\right)$ for each phytoestrogen were above 0.998. Formononetin, biochanin A, and prunetin were not detectable in analyzed alfalfa samples. The sample preparation and HPLC method used in this work were previously validated by Ramos et al. [31].

\subsection{Statistical Analysis}

The analysis of the collected experimental data was processed using the STAR v. 2.0.1 [32] software. The data were subjected to analysis of variance (ANOVA) to enable an LSD calculation. Fisher's protected LSD test was used at the 0.05 and 0.01 probability level to identify significant differences between the mean values of populations. A hierarchical cluster analysis was performed using the Ward method, by means of which the alfalfa populations were grouped according to the analyzed phytoestrogen contents and major agronomic traits.

\section{Results and Discussion}

\subsection{Phytoestrogen Profiles}

The HPLC profile of the identified phytoestrogens in the leaves extract of the alfalfa populations is shown in Figure 1. The most abundant phytoestrogen in the alfalfa populations was genistein, with a share of $30.33 \%$ in the total amount of phytoestrogens. A slightly lower content was found for both kaempferol and coumestrol (26.84 and 25.02\%), while the presence of glycitein and daidzein (14.84 and $2.97 \%$ ) in the total amount of phytoestrogens of all alfalfa populations was significantly lower (Figure 2).

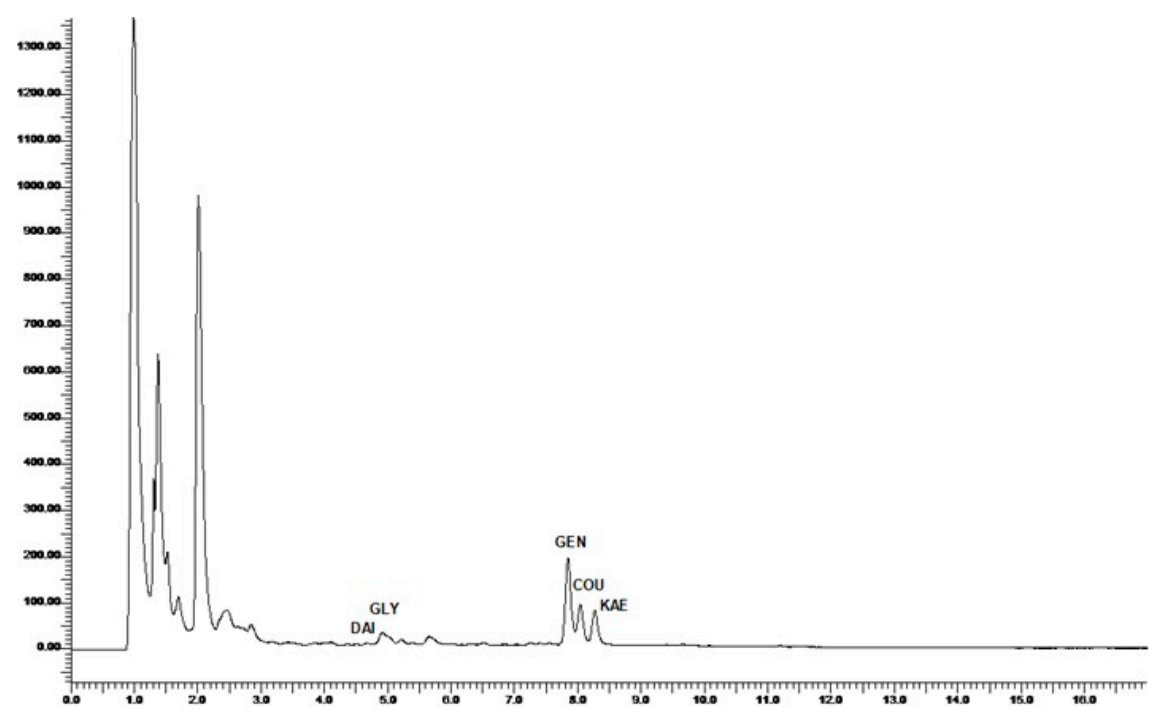

Figure 1. HPLC-DAD chromatogram of the phytoestrogens identified in alfalfa leaves extract (DAI—daidzein, GLY—glycitein, GEN—genistein, COU—coumestrol, KAE-kaempferol). 


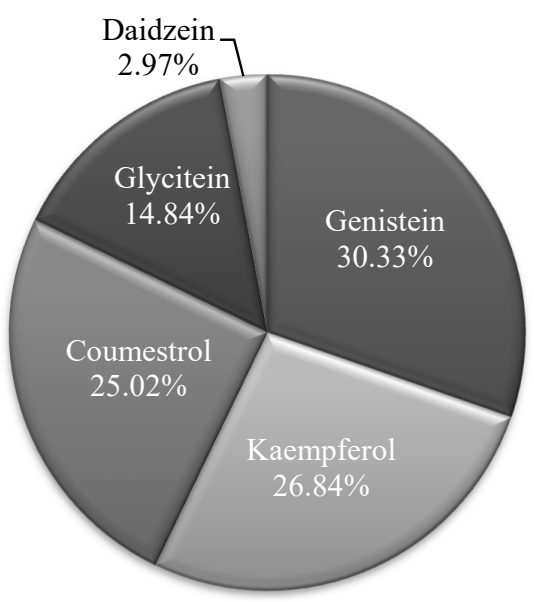

Figure 2. Proportion (\%) of individual phytoestrogens in the total amount of all alfalfa populations.

\subsection{Variation of Phytoestrogens and Agronomic Traits}

Analysis of variance revealed statistically significant differences between the alfalfa populations, as well as a significant influence of population $\times$ year interaction for all of the investigated traits. Significant influence of years as a source of variability was found in the investigated alfalfa materials tested for agronomic traits, while no statistical significance was determined for the content of most of the individual phytoestrogens as well for the total content of phytoestrogens (Table 2).

In the second year of research, compared to the first year, higher values were determined for all tested agronomic traits in the investigated alfalfa populations, which was expected since alfalfa is a perennial species that reaches its maximum potential for productivity in the second and third cultivation year. Similar values were observed for the individual phytoestrogen content and total phytoestrogen content in both investigated years.

\subsubsection{Agronomic Traits}

The major agronomic traits across the two-year average for the 20 observed alfalfa populations varied from 62.13 to $71.93 \mathrm{t} \mathrm{ha}^{-1}$ for green mass yield, 18.87 to $20.64 \%$ for DM content, and 60.74 to $67.89 \mathrm{~cm}$ for plant height, with significant differences among the populations (Table 2). The alfalfa populations Af 1, 12, 14, 18, 19, 20 showed a good agronomic performance, and they are valuable for breeding programs to develop high yielding cultivars. The above-mentioned populations achieved higher yield of green mass, compared to the average value of all the investigated alfalfa populations, indicating their pronounced genetic potential for yield. Forage yield is of primary interest for all forage legume breeders along with creation of populations with greater yielding, as in our research where Af 18 and 20 recorded up to 13.6\% higher yields compared to the least yielding populations. This demonstrates the successful breeding strategy used in our perennial forage legume programs.

\subsubsection{Phytoestrogen Content}

Statistically significant differences were observed in phytoestrogen contents among the tested populations. The highest average content of daidzein, glycitein, and coumestrol was found in the Af 19 population $\left(83.27,440.99\right.$, and $686.53 \mu^{-1} \mathrm{~g}^{-1}$ of $\left.\mathrm{DM}\right)$, as well as high total content of phytoestrogens $\left(2476.83 \mu \mathrm{g} \mathrm{g}^{-1}\right.$ of DM). The highest content of genistein $\left(836.50 \mu \mathrm{g} \mathrm{g}^{-1}\right.$ of DM) was recorded in the Af 6 population, while the Af 7 population showed the highest content of kaempferol $\left(760.30 \mu \mathrm{g} \mathrm{g}{ }^{-1}\right.$ of $\mathrm{DM})$. The highest total content of all phytoestrogens $\left(2637.10 \mu \mathrm{g} \mathrm{g}^{-1}\right.$ of DM) was found in the Af 8 population which also achieved high amounts of majority of the individual components. The Af 1 population had the lowest total content of phytoestrogens, and the lowest content of both glycitein and coumestrol $\left(1849.47,218.51\right.$, and $445.90 \mathrm{\mu g} \mathrm{g}^{-1}$ of DM). Low levels of total phytoestrogens and most of the individual phytoestrogens were also determined in the Af 12, 17, and 20 populations. 
Table 2. The average values of the investigated agronomical traits (GMY—green mass yield in $\mathrm{t} \mathrm{ha}^{-1}$, DMC—dry matter content in \%, PH—plant height in $\mathrm{cm}$ ) and phytoestrogen content (DAI—daidzein, GLY—glycitein, GEN—genistein, COU—coumestrol, KAE—kaempferol, TOT CON—total content in $\mu \mathrm{g} \mathrm{g}^{-1}$ of DM) of the 20 alfalfa populations.

\begin{tabular}{|c|c|c|c|c|c|c|c|c|c|}
\hline $\mathbf{P}$ & GMY & DMC & PH & DAI & GLY & GEN & $\mathrm{COU}$ & KAE & TOT CON \\
\hline Af1 & 67.96 & 20.27 & 64.24 & 53.20 & 218.51 & 600.24 & 445.90 & 531.62 & 1849.47 \\
\hline Af2 & 63.61 & 20.06 & 62.64 & 57.26 & 296.91 & 617.61 & 538.56 & 598.58 & 2108.92 \\
\hline Af3 & 64.58 & 20.64 & 60.74 & 64.27 & 390.37 & 770.58 & 543.98 & 621.14 & 2390.33 \\
\hline Af4 & 62.90 & 20.30 & 62.55 & 77.50 & 296.78 & 790.56 & 631.28 & 681.16 & 2477.27 \\
\hline Af5 & 64.85 & 19.56 & 62.47 & 79.37 & 377.96 & 748.27 & 579.90 & 644.71 & 2430.21 \\
\hline Af6 & 62.13 & 20.21 & 64.23 & 43.61 & 252.61 & 836.50 & 614.61 & 560.86 & 2308.19 \\
\hline Af7 & 63.20 & 19.92 & 61.37 & 54.46 & 264.26 & 737.49 & 625.42 & 760.30 & 2441.92 \\
\hline Af8 & 65.82 & 19.56 & 64.45 & 60.84 & 399.93 & 797.20 & 672.21 & 706.92 & 2637.10 \\
\hline Af9 & 65.56 & 19.26 & 67.89 & 67.98 & 315.59 & 668.26 & 547.02 & 560.26 & 2159.11 \\
\hline Af10 & 66.52 & 19.78 & 64.68 & 61.42 & 352.01 & 715.39 & 576.51 & 558.84 & 2264.17 \\
\hline Af11 & 65.39 & 19.53 & 65.03 & 65.60 & 343.11 & 709.09 & 584.57 & 619.46 & 2321.84 \\
\hline Af12 & 69.45 & 19.07 & 62.35 & 77.68 & 330.90 & 594.30 & 509.12 & 574.01 & 2086.01 \\
\hline Af13 & 66.24 & 19.97 & 63.87 & 74.47 & 428.00 & 627.97 & 577.38 & 576.15 & 2283.97 \\
\hline Af14 & 68.88 & 18.87 & 65.23 & 72.21 & 325.36 & 773.01 & 595.47 & 612.87 & 2378.91 \\
\hline Af15 & 62.62 & 19.79 & 63.95 & 67.15 & 315.58 & 727.64 & 511.83 & 523.46 & 2145.66 \\
\hline Af16 & 64.46 & 19.59 & 62.78 & 78.44 & 299.74 & 573.42 & 566.54 & 709.56 & 2227.70 \\
\hline Af17 & 65.24 & 19.38 & 62.90 & 72.96 & 304.93 & 540.56 & 552.50 & 617.56 & 2088.51 \\
\hline Af18 & 71.93 & 19.69 & 65.48 & 71.28 & 434.38 & 678.19 & 498.52 & 554.14 & 2236.51 \\
\hline Af19 & 70.68 & 19.38 & 64.59 & 83.27 & 440.99 & 663.49 & 686.53 & 602.55 & 2476.83 \\
\hline Af20 & 71.66 & 19.80 & 67.33 & 66.51 & 352.59 & 602.83 & 503.72 & 575.04 & 2100.69 \\
\hline Average & 66.18 & 19.73 & 63.94 & 67.47 & 337.00 & 688.63 & 568.08 & 609.46 & 2270.67 \\
\hline MS y & $92,553.95 * *$ & $45.99 * *$ & $5771.2 * *$ & $381.75 \mathrm{~ns}$ & $46,501.26^{*}$ & $29,414.02 * *$ & $0.68 \mathrm{~ns}$ & $9412.83 \mathrm{~ns}$ & $254,552.92 \mathrm{~ns}$ \\
\hline MS p & 71.22 ** & $1.54^{* *}$ & $25.82 * *$ & $415.64^{* *}$ & $14,895.40$ ** & $28,553.05$ ** & $14,385.83$ ** & $16,115.02$ ** & $133,759.50 * *$ \\
\hline MS y × p & $14.15^{*}$ & $0.92 * *$ & $15.82^{* *}$ & $713.00 * *$ & $19,698.71^{* *}$ & $7971.62 * *$ & $6529.52 * *$ & $7285.57^{* *}$ & $50,879.93$ ** \\
\hline LSD $0.05 p$ & 4.01 & 0.11 & 2.85 & 2.74 & 15.42 & 9.64 & 12.04 & 21.13 & 30.37 \\
\hline LSD $0.01 p$ & 5.31 & 0.14 & 3.82 & 3.67 & 20.66 & 12.92 & 16.13 & 28.30 & 40.68 \\
\hline
\end{tabular}

MS—-mean square, $\mathrm{y}-$ year, $\mathrm{p}$-population, $\mathrm{y} \times \mathrm{p}$-interaction year and population, significance level is marked at $p \leq 0.05\left(^{*}\right)$ and $0.01\left(^{* *}\right)$, ns-not significant. 
Many factors affect the content of phytoestrogens including genetic factors (plant genotype), environmental conditions (temperature, rainfall, humidity, sunlight), biotic factors (fungal diseases), stages of maturity (early vegetative-late flower), stand age of alfalfa, plant parts (leaves, stems and flowers), management strategies (cutting frequency), and preservation method [16,26,33,34]. Conducted studies and currently available data on quantification of the phytoestrogen content in alfalfa show that their amount is highly variable and results are very often inconsistent $[35,36]$. Martin et al. [37] found that the highest average content of coumestrol was $99 \mu \mathrm{g} \mathrm{g}^{-1}$ of DM, followed by formononetin, daidzein, biochanin $\mathrm{A}$, and genistein with $43,21,19$, and $14 \mu \mathrm{g} \mathrm{g}^{-1}$ of DM, respectively. Moravcova et al. [27] reported that coumestrol content in alfalfa cultivar Morava ranged between 148 and $248 \mu \mathrm{g} \mathrm{g}^{-1}$ of DM, while Butkute et al. [38] quantified content which ranged between 30 and $32.6 \mu \mathrm{g} \mathrm{g}^{-1}$. Seguin et al. [33] studied the effect of plant maturity and herbage components on phytoestrogen content in field-grown alfalfa and determined that the content of individual phytoestrogens in whole herbage ranged from 15 to $225 \mathrm{\mu g} \mathrm{g}^{-1}$ of DM. Fields et al. [39] assessed individual effects of agronomic factors (cutting frequency, development stage, and cultivar) in both the field and greenhouse on coumestrol content in alfalfa and concluded that fungal pathogens infection and inoculation treatment significantly increased coumestrol content, while development stage had no effect. Elevated levels of coumestrol in alfalfa herbage were also observed because of pea aphid herbivory [39].

The determined values of the investigated phytoestrogens in this study are slightly higher than the results obtained by the above-mentioned authors, which is most likely related to the known fact that the highest amount of phytoestrogens accumulates in the leaves of forage legumes [16,17,26]. Also, good weather conditions during the alfalfa vegetation period in both years, favorable air temperatures and higher total amount of precipitation, compared to the long-term average (Table 1), certainly contributed to the higher phytoestrogen accumulation in the studied alfalfa populations. While developing a model to predict coumestrol content in non-irrigated alfalfa crops using weather variables Fields et al. [34] concluded that rainfall is a major component in the model. They determined that during wet years with a lot of rainfall coumestrol contents are elevated.

\subsection{Cluster Analysis of Alfalfa Populations Based on Agronomic and Phytoestrogen Data}

Ward hierarchical clustering method was conducted to identify the different groups of alfalfa populations according to phytoestrogen content and major agronomic traits. Clustering of the data grouped the 20 evaluated populations into four distinct clusters (C1-4) (Figure 3). C1 is the most numerous cluster containing nine populations (Af 10,11,9,14, 5, 13, 19, 18, 20) followed by two clusters of four populations each (C2: Af 4, 7, 8, 3 and C3: Af 2, 15, 1, 6), while the smallest $C 4$ cluster contained Af 16, 17, 2 populations.

Most populations in the $\mathrm{C} 1$ are characterized by medium to superior agronomic performances and average to lower phytoestrogen content, except for Af 19 which had high content of most of the individual and total phytoestrogens. Populations clustered in $\mathrm{C} 2$ are characterized by high content of phytoestrogens and lower values of important agronomic traits. C3 contained alfalfa materials that showed lower values for all of the studied phytoestrogens as well as for the observed agronomic properties, except for Af 1 which showed favorable forage performances. Populations clustered in C4 had average values for all of the studied traits, except for Af 12 in which a low content of most of the individual and total phytoestrogens and very favorable agronomic properties were found. This analysis revealed a large range of genetic variations of the investigated traits that contributed to the structuring of the diversity of the studied alfalfa populations into several different similarity groups. Also, other numerous forage crops researchers in their investigations used clustering analysis for grouping various genotypes/populations/cultivars/accessions/ based on the contribution of morpho-agronomic and/or biochemical characteristics [40-44]. Little et al. [41] assessed phytoestrogens and agronomic traits on a broad range of red clover cultivars and accessions. They detected significant genetic variation for key agronomic traits and for main phytoestrogens and by multivariate analysis grouped 
64 accessions into ten distinct clusters that had between 1 and 10 members. Abidi et al. [43] analyzed the antioxidant compounds and the secondary metabolites (total phenols, tannins, and saponins) in different plant parts of eight populations of Medicago ciliaris L. collected in different bioclimatic areas of north Tunisia. Significant differences between populations for several parameters were detected, and dendrogram cluster analysis for grouping studied populations was applied. Tucak et al. [42] determined a variation in the isoflavone contents of 29 red clover cultivars/populations and identified valuable materials by biplot analysis that is used in our current breeding strategies for the development of specific cultivars.

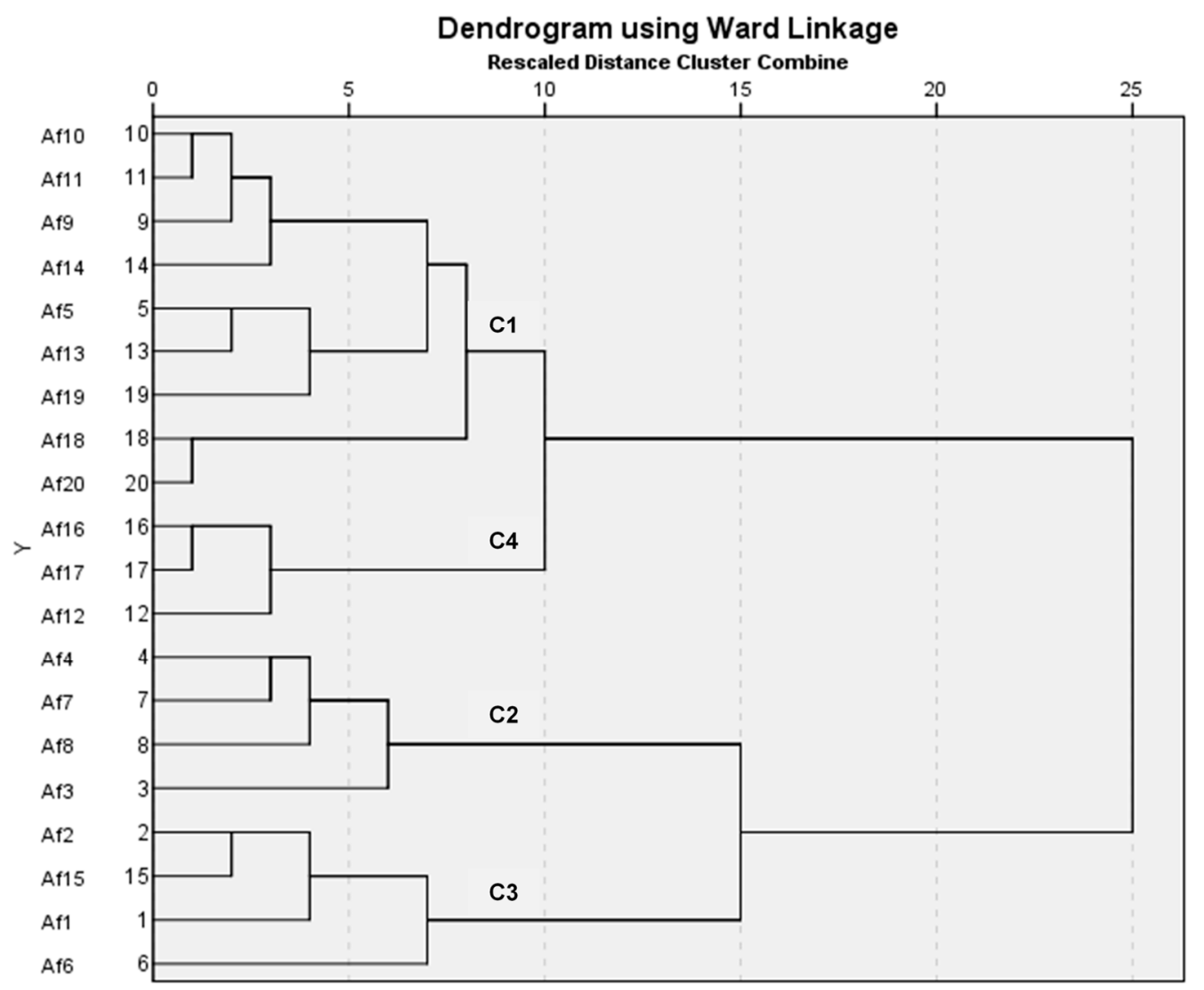

Figure 3. Dendrogram of the 20 alfalfa populations by analyzing traits using Ward cluster analysis method.

\section{Conclusions}

Significant genetic variation for the individual and the total content of phytoestrogens and agronomic traits was found between alfalfa populations under study. The most dominant phytoestrogen in alfalfa populations was genistein while slightly lower levels were found for kaempferol and coumestrol. Several populations (Af 1, 12, 18, 19, 20) with superior agronomic performance have been identified, primarily with high forage yield, which is the main objective of the breeding programs for perennial forage legumes. These populations were also characterized by a lower (Af 1, 12, 18, 20) or high (Af 1, 19) content of total and individual phytoestrogens, including Af 8 population with the highest phytoestrogen content and most of the individual phytoestrogen contents and favorable agronomic properties. Identified materials provide a valuable source of germplasm for our breeding programs to develop new high yielding cultivars with either low (for forage use) or high (for possible pharmaceuticals/nutraceuticals industries) phytoestrogen content. 
Author Contributions: Conceptualization, M.T. and D.H.; methodology, S.P.; software, T.Č.; biochemical analysis, D.H.; investigation, M.T.; data curation, G.K. and T.Č.; writing-Original draft, M.T.; writing-Review and editing, M.T. and M.R.; supervision, S.P. All authors have read and agreed to the published version of the manuscript.

Funding: This work was supported by Program of Continuous scientific work on the creation of new varieties of forage crops at the Agricultural Institute Osijek.

Acknowledgments: The authors would like to thank the Agricultural Institute Osijek, Department of Small Cereal Crops and Department-Agrochemical Laboratory, and the Faculty of Food Technology Osijek, Josip Juraj Strossmayer University of Osijek, Osijek for the technical support.

Conflicts of Interest: The authors declare no conflict of interest.

\section{References}

1. Russelle, M.P. Environmental benefits of growing perennial legumes in cropping systems. Legume Perspect. 2014, 4, 11-12.

2. Annicchiarico, P. Alfalfa forage yield and leaf/stem ratio: Narrow-sense heritability, genetic correlation, and parent selection procedures. Euphytica 2015, 205, 409-420. [CrossRef]

3. Annicchiarico, P.; Barrett, B.; Brummer, E.C.; Julier, B.; Marshall, A.H. Achievements and challenges in improving temperate perennial forage legumes. Crit. Rev. Plant Sci. 2015, 34, 327-380. [CrossRef]

4. Vasileva, V.; Kostov, O. Effect of mineral and organic fertilization on alfalfa forage and soil fertility. Emir. J. Food Agric. 2015, 27, 678-686. [CrossRef]

5. Shi, S.; Nan, L.; Smith, K.F. The Current Status, Problems, and Prospects of Alfalfa (Medicago sativa L.) Breeding in China. Agronomy 2017, 7, 1. [CrossRef]

6. Kř́žová, L.; Dadáková, K.; Kašparovská, J.; Kašparovský, T. Isoflavones. Molecules 2019, 24, 1076. [CrossRef]

7. Lipovac, M.; Chedraui, P.; Gruenhut, C.; Gocan, A.; Kurz, C.; Neuber, B.; Imhof, M. The effect of red clover isoflavone supplementation over vasomotor and menopausal symptoms in postmenopausal women. Gynecol. Endocrinol. 2012, 28, 203-207. [CrossRef]

8. Sirotkin, V.A.; Harrath, A.H. Phytoestrogens and their effects. Eur. J. Pharmacol. 2014, 741, 230-236. [CrossRef]

9. Gatouillat, G.; Magid, A.A.; Bertin, E.; Okiemy-Akeli, M.G.; Morjani, H.; Lavaud, C.; Madoulet, C. Cytotoxicity and Apoptosis Induced by Alfalfa (Medicago sativa) Leaf Extracts in Sensitive and Multidrug-Resistant Tumor Cells. Nutr. Cancer 2014, 66, 483-491. [CrossRef]

10. Nabatchian, F.; Aghoosi, S.M.H.; Mordadi, A.; Khodaverdi, F. Evaluation of the effect of alfalfa extract on breast cancer. J. Appl. Environ. Biol. Sci. 2015, 4, 288-294.

11. Shakeri, F.; Taavoni, S.; Goushegir, A.; Haghani, H. Effectiveness of red clover in alleviating menopausal symptoms: A 12-week randomized, controlled trial. Climacteric 2015, 18, 568-573. [CrossRef] [PubMed]

12. Abdi, F.; Alimoradi, A.; Hagi, P.; Mahdizad, F. Effects of phytoestrogens on bone mineral density during the menopause transition: A systematic review of randomized controlled trials. Climacteric 2016, 19, 535-545. [CrossRef]

13. Chen, M.N.; Lin, C.C.; Liu, C.F. Efficacy of phytoestrogens for menopausal symptoms: A meta-analysis and systematic review. Climacteric 2016, 18, 260-269. [CrossRef] [PubMed]

14. Gopal, N.M.; Tejaswini, J.; Mantry, S.; Kumar, A. International standards of medicinal plants. Int. J. Innov. Pharm. Sci. Res. 2014, 2, 2498-2532.

15. Aparicio-Fernandez, X.; Yousef, G.G.; Loarca-Pina, G.; de Mejia, E.; Lila, M.A. Characterization of polyphenolics in the seed coat of black jamapa bean (Phaseolus vulgaris L.). J. Agric. Food Chem. 2005, 53, 4615-4622. [CrossRef] [PubMed]

16. Saviranta, N.M.M.; Anttonen, M.J.; von Wright, A.; Karjalainen, R.O. Red clover (Trifolium pratense L.) isoflavones: Determination of concentrations by plant stage, flower colour, plant part and cultivar. J. Sci. Food Agric. 2008, 88, 125-132. [CrossRef]

17. Butkute, B.; Lemeziene, N.; Dabkeviviene, G.; Jakstas, V.; Vilcinskas, E.; Janulis, V. Source of variation of isoflavone concentrations in perennial clover species. Pharmacogn. Mag. 2014, 10, 181-188. [CrossRef]

18. Moorby, J.M.; Fraser, M.D.; Theobald, V.J.; Wood, J.D.; Haresign, W. The effect of red clover formononetin concentration on live-weight gain, carcass characteristics and muscle equol concentration of finishing lambs. Anim. Sci. 2004, 79, 303-313. [CrossRef] 
19. Rodrigues, F.; Almeida, I.; Sarmento, B.; Amaral, M.H.; Oliveira, P.P.M.B. Study of the isoflavone content of different extracts of Medicago spp.as potential active ingredient. Ind. Crops Prod. 2014, 57, 110-115. [CrossRef]

20. Mustonen, E.A.; Tuori, M.; Saastamoinen, I.; Taponen, J.; Wahala, K.; Saloniemi, H.; Vanhatalo, A. Equol in milk of dairy cows is derived from forage legumes such as red clover. Br. J. Nutr. 2009, 102, 1552-1556. [CrossRef]

21. Kalač, P. Fresh and ensiled forages as a source of estrogenic equol in bovine milk: A review. Czech J. Anim. Sci. 2013, 58, 296-303. [CrossRef]

22. Adler, S.A.; Purup, S.; Hansen-Moller, J.; Thuen, E.; Steinshamn, H. Phytoestrogens and Their Metabolites in Bulk-Tank Milk: Effects of Farm Management and Season. PLoS ONE 2015, 10, e0127187. [CrossRef]

23. Mustonen, E. Red Clover Isoflavonoids in Feed, Plasma and Milk of Ruminants. Ph.D. Thesis, The Faculty of Veterinary Medicine, University of Helsinki, Helsinki, Finland, 2015.

24. Daems, F.; Romnee, J.M.; Heuskin, S.; Froidmont, E.; Lognay, G. Analytical methods used to quantify isoflavones in cow's milk: A review. Dairy Sci. Technol. 2016, 96, 261-283. [CrossRef] [PubMed]

25. Kasparovska, J.; Pecinkova, M.; Dadakova, K.; Krizova, L.; Hadrova, S.; Lexa, M.; Lochman, J.; Kasparovsky, T. Effects of Isoflavone-Enriched Feed on the Rumen Microbiota in Dairy Cows. PLoS ONE 2016, 11, e0154642. [CrossRef] [PubMed]

26. Sivesind, E.; Seguin, P. Effects of the environment, cultivar, maturity, and preservation method on red clover isoflavone concentration. J. Agric. Food Chem. 2005, 53, 6397-6402. [CrossRef] [PubMed]

27. Moravcova, J.; Kleinova, T.; Loučka, R. The determination of coumestrol in alfalfa (Medicago sativa) by capillary electrophoresis. Rostlinná Vyroba 2002, 48, 224-229. [CrossRef]

28. Visnevschi-Necrasov, T.; Faria, M.A.; Cunha, S.C.; Harris, J.; Meimberg, H.W.E.; Curto, M.A.C.; Pereira, M.G.; Oliveira, M.B.P.P.; Nunes, E. Isoflavone synthase (IFS) gene phylogeny in Trifolium species associated with plant isoflavone contents. Plant Syst. Evol. 2013, 299, 357-367. [CrossRef]

29. Reed, K.F.M. Fertility of Herbivores Consuming Phytoestrogen-Containing Medicago and Trifolium Species. Agriculture 2016, 6, 35. [CrossRef]

30. Hloucalova, P.; Skladanka, J.; Horky, J.; Klejdus, B.; Pelikan, J.; Knotova, K. Determination of phytoestrogen content in fresh-cut legume forage. Animals 2016, 6, 43. [CrossRef]

31. Ramos, G.P.; Dias, P.M.B.; Morais, C.B.; Fröehlich, P.E.; Dall’Agnol, M.; Zuanazzi, J.A.S. LC determination of four isoflavone aglycones in red clover (Trifolium pratense L.). Chromatographia 2008, 67, 125-129. [CrossRef]

32. IRRI. Statistical Tool for Agricultural Research (STAR) Version: 2.0.1; International Rice Research Institute: Los Baños, Philippines, 2013.

33. Seguin, P.; Zheng, W.; Souleimanov, A. Alfalfa phytoestrogen content: Impact of plant maturity and herbage components. J. Agron. Crop Sci. 2004, 190, 211-217. [CrossRef]

34. Fields, R.L.; Sedcole, J.R.; Barrell, G.K.; Moot, D.J. Prediction of coumestrol content in unirrigated lucerne crops using weather variables. N. Z. J. Agric. Res. 2019, 62, 528-542. [CrossRef]

35. Seguin, P.; Zheng, W. Phytoestrogen content of alfalfa cultivars grown in eastern Canada. J. Sci. Food Agric. 2006, 86, 765-771. [CrossRef]

36. Tucak, M.; Horvat, D.; Čupić, T.; Krizmanić, G.; Tomaš, V.; Ravlić, M.; Popović, S. Forage Legumes as Sources of Bioactive Phytoestrogens for Use in Pharmaceutics: A Review. Curr. Pharm. Biotechnol. 2018, 19, 537-544. [CrossRef] [PubMed]

37. Martin, L.M.; Castilho, M.C.; Silveira, I.; Abreu, J.M. Liquid chromatographic validation of a quantitation method for phytoestrogens, biochanin-A, coumestrol, daidzein, formononetin, and genistein, in lucerne. J. Liq. Chromatogr. Relat. Technol. 2006, 29, 2875-2884. [CrossRef]

38. Butkute, B.; Padarauskas, A.; Ceseviciene, J.; Pavilonis, A.; Taujenis, L.; Lemeziene, N. Perennial legumes as a source of ingredients for healthy food: Proximate, mineral and phytoestrogen composition and antibacterial activity. J. Food Sci. Technol. 2017, 54, 2661-2669. [CrossRef] [PubMed]

39. Fields, R.L.; Barrell, G.K.; Gash, A.; Zhao, J.; Moot, D.J. Alfalfa Coumestrol Content in Response to Development Stage, Fungi, Aphids, and Cultivar. Agron. J. 2018, 110, 910-921. [CrossRef]

40. Ramos, G.P.; Dias, P.M.B.; Morais, C.B.; Dall'Agnol, M.; Zuanazzi, J.A.S. Genetic variability of isoflavones in the USDA red clover core collection. Rev. Bras. Farmacogn. 2012, 22, 1241-1252. [CrossRef]

41. Little, V.; Reed, K.F.M.; Smith, K.F. Variation for concentrations of various phytoestrogens and agronomic traits among a broad range of red clover (Trifolium pratense) cultivars and accessions. Agronomy 2017, 7, 34. [CrossRef] 
42. Tucak, M.; Popović, S.; Horvat, D.; Čupić, T.; Krizmanić, G.; Viljevac Vuletić, M.; Ravlić, M. The characterization of isoflavone content in the Croatian red clover collection. Poljoprivreda 2019, 25, 3-11. [CrossRef]

43. Abidi, S.; Jabri, C.; Souissi, A.; Ferchichi, M.; Zoghlami-Khélil, A. Comparative analysis of antioxidant and secondary metabolites contents in eight populations of Medicago ciliaris L. J. Anim. Plant Sci. 2019, 41, 7042-7054. [CrossRef]

44. Egan, L.M.; Hofmann, R.W.; Ghamkhar, K.; Hoyos-Villegas, V. Identification of Founding Accessions and Patterns of Relatedness and Inbreeding Derived from Historical Pedigree Data in a Red Clover Germplasm Collection in New Zealand. Crop Sci. 2019, 59, 2100-2108. [CrossRef]

(C) 2020 by the authors. Licensee MDPI, Basel, Switzerland. This article is an open access article distributed under the terms and conditions of the Creative Commons Attribution (CC BY) license (http://creativecommons.org/licenses/by/4.0/). 